\title{
Kawasaki disease presenting after intussusception: a case report
}

\author{
Rukhsar Shabir Osman ${ }^{1 *}$, Hajaj Mohamed Salum² and Mariam Noorani ${ }^{1}$
}

\begin{abstract}
Introduction: Kawasaki disease is a common vasculitis of unknown etiology that occurs mainly in preschool children. It manifests as a self-limited acute febrile illness with other features including extremity changes, cervical lymphadenopathy, oropharyngeal changes, truncal rash, and conjunctivitis. Intestinal involvement is not uncommon, with abdominal pain and vomiting being the most frequently reported symptoms. Intussusception has been described as a manifestation or complication of this disease, but few reports exist in literature.
\end{abstract}

Case presentation: A 7-month-old boy of Asian origin who presented with vomiting and passage of bloody mucoid stool was diagnosed with intussusception that was successfully reduced during emergency laparotomy. The baby was discharged home post-surgery following clinical improvement. He was readmitted on the fourth postoperative day with fever, irritability, and diarrhea. He was investigated and treated for presumed intraabdominal sepsis with multiple antibiotics with no improvement. He gradually developed the mucocutaneous features of Kawasaki disease and was treated with intravenous immunoglobulin and aspirin with good outcome.

Conclusion: Intussusception and Kawasaki disease both commonly occur in children less than 2 years old. It is important to include Kawasaki disease as a differential diagnosis in children of this age who present with an acute febrile illness and gastrointestinal symptoms. A common underlying pathologic process could be contributing to both conditions.

Keywords: Intussusception, Kawasaki, Tanzania, Fever

\section{Background}

Kawasaki disease (KD) is an acute febrile vasculitic syndrome of childhood. It was first reported by its namesake, Dr. Tomisaku Kawasaki, in 1967 in Japan. It has been noted in all ethnic origins, with highest incidence being reported among children of Asian origin [1]. Despite sporadic cases being reported across many countries in Africa, particularly North and West African regions, the epidemiological data for KD are limited for African countries [2].

A disease once thought to be benign and self-limited is actually a leading cause of acquired heart disease among

\footnotetext{
*Correspondence: rukhsaarosman@gmail.com

${ }^{1}$ Aga Khan Hospital, Dar es Salaam, Tanzania

Full list of author information is available at the end of the article
}

children in developed countries and a risk factor for adult ischemic heart disease [1] .

The cause of this disease is to date unknown; however, multiple theories have been proposed, ranging from genetic and environmental factors to infectious etiology [3] .

Kawasaki disease has been categorized into complete (typical) and incomplete (atypical) disease. Diagnostic criteria for typical disease are fever for at least 5 days without an explanation, plus any four of the following five: bilateral bulbar conjunctival congestion; polymorphous rash; acute nonpurulent cervical lymphadenopathy; changes of the lips and oral cavity (red or fissured lips, strawberry tongue, diffuse injection of pharyngeal mucosa); or peripheral extremity changes including erythema of palms or soles, edema of hands or feet (acute original author(s) and the source, provide a link to the Creative Commons licence, and indicate if changes were made. The images or other third party material in this article are included in the article's Creative Commons licence, unless indicated otherwise in a credit line to the material. If material is not included in the article's Creative Commons licence and your intended use is not permitted by statutory regulation or exceeds the permitted use, you will need to obtain permission directly from the copyright holder. To view a copy of this licence, visit http://creativecommons.org/licenses/by/4.0/. The Creative Commons Public Domain Dedication waiver (http://creativeco mmons.org/publicdomain/zero/1.0/) applies to the data made available in this article, unless otherwise stated in a credit line to the data. 
phase), and periungual desquamation (convalescent phase). The characteristic features can be preceded by nonspecific gastrointestinal or respiratory symptoms such as diarrhea, vomiting, abdominal pain, decreased intake, irritability or cough, and rhinorrhea. Diagnosis can be delayed in those initially presenting with gastrointestinal symptoms [3].

A high index of suspicion is necessary to identify cases of Kawasaki disease and initiate early treatment, since children in sub-Saharan Africa suffer from many tropical and infectious diseases that present with symptoms similar to those of Kawasaki disease such as fever, irritability, and a rash. These include malaria, typhoid fever, meningitis, viral exanthem such as measles and roseola infantum, and infection with group A beta hemolytic streptococcus [2].

This is a report of a patient with Kawasaki disease associated with intussusception who was admitted at our hospital.

\section{Case report}

A 7-month-old fully vaccinated Asian boy was presented with 1 day history of nonbilious, nonprojectile vomiting, and passage of bloody mucoid stool (Table 1). There was no history of fever or upper respiratory infection. He had been introduced to complementary feeding consisting of cow's milk and formula feeding, 2 weeks prior to illness.

He was delivered at 36 weeks gestation age to a mother with gestational diabetes, with an Apgar score of $9^{1}$ and
$10^{5}$, and required continuous positive airway pressure (CPAP) at birth because of respiratory distress.

On examination, he was irritable with dry oral mucosa, warm extremities with capillary refill $<2$ seconds, pulse rate 133 beats per minute, and respiratory rate 40 breaths per minute. His throat was not hyperemic, and tympanic membrane was clear, lung fields were clear with vesicular breath sounds bilaterally, no added sounds were heard on auscultation of the heart, and in the abdomen no tenderness or palpable mass was felt. On anal examination, there was no obvious fissure, and on digital examination, there was no palpable mass and gloved finger was stained with mucoid feces mixed with streaks of fresh blood.

A provisional diagnosis of intussusception was made and confirmed on abdominal ultrasound, which showed a target sign at the right upper quadrant with peripheral vascularity, highly suspicious of intussusception (Fig. 1). Laboratory tests showed initial C-reactive protein (CRP) $3.05 \mathrm{mg} / \mathrm{L}$, white blood cells (WBC) $16.13 \times 10^{9} / \mathrm{L}$, neutrophils $64.4 \%$, lymphocytes $30.8 \%$, platelets $466 \times 10^{9} / \mathrm{L}$, and hemoglobin $10.7 \mathrm{~g} / \mathrm{dL}$. Laparotomy was performed with intraoperative findings of ileocolic intussusception with viable bowel, and manual reduction was done. The child was started on intravenous ceftriaxone $75 \mathrm{mg} / \mathrm{kg} /$ day and intravenous metronidazole $30 \mathrm{mg} / \mathrm{kg} /$ day. He had an uneventful postoperative period and was discharged 2 days later on oral antibiotics.

The child presented again on the fourth day postlaparotomy after having developed high-grade fevers

Table 1 Time line of events

\begin{tabular}{|c|c|c|c|}
\hline Date & Summary from initial and follow-up visits & Diagnostic testing & Intervention \\
\hline $\begin{array}{l}\text { April } 2019 \\
\text { Day } 1\end{array}$ & $\begin{array}{l}\text { One-day history of vomiting and mucoid } \\
\text { bloody stool. On examination, gloved fin- } \\
\text { ger stained with mucoid feces mixed with } \\
\text { streaks of fresh blood. Diagnosis: possible } \\
\text { intussusception }\end{array}$ & $\begin{array}{l}\text { CRP } 3.05 \mathrm{mg} / \mathrm{L}, \\
\text { WBC: } 16.13 \times 10^{9} / \mathrm{L} \text {, platelets: } 466 \times 10^{9} / \mathrm{L} \text {, } \\
\text { Hb: } 10.7 \mathrm{~g} / \mathrm{dL} \text {, abdominal ultrasound: } \\
\text { target sign at right upper quadrant with } \\
\text { peripheral vascularity }\end{array}$ & $\begin{array}{l}\text { Laparotomy and manual reduction of the } \\
\text { intussusception. Initiation of ceftriaxone } \\
\text { and metronidazole }\end{array}$ \\
\hline Day 3 & Child doing well & & Discharged on cefixime and metronidazole \\
\hline Day 4 & $\begin{array}{l}\text { High-grade fevers and diarrhea. Examina- } \\
\text { tion: irritable, febrile, tachycardic with } \\
\text { some dehydration, no lymphadenopathy, } \\
\text { delayed capillary refill with peripheral } \\
\text { cyanosis, and maculopapular rash on the } \\
\text { back and at BCG scar site. Hyperactive } \\
\text { bowel sounds and clean surgical wound. } \\
\text { Diagnosis: sepsis }\end{array}$ & $\begin{array}{l}\text { CRP: } 121 \mathrm{mg} / \mathrm{L} \text {, } \\
\text { WBC: } 16.83 \times 10 \text {, platelets: } 428 \times 10^{9} / \mathrm{L}, \mathrm{Hb} \text { : } \\
\quad 9.1 \mathrm{~g} / \mathrm{dL}^{9} / \mathrm{L} \text {, } \\
\text { stool routine, urine routine: normal } \\
\text { Abdominal X-ray: normal }\end{array}$ & $\begin{array}{l}\text { IV amikacin + IV ceftriaxone + IV metroni- } \\
\text { dazole } \\
\text { IV fluid bolus, then IV DNS at maintenance } \\
\text { rate, } \\
\text { zinc sulfate } 20 \text { mg, ibuprofen, and par- } \\
\text { acetamol }\end{array}$ \\
\hline Day 5 & $\begin{array}{l}\text { Persistent fever and irritability, nonpitting } \\
\text { feet swelling, bilateral nonpurulent con- } \\
\text { junctivitis sparing the limbus }\end{array}$ & Dengue serology: negative & Antibiotics continued \\
\hline Day 6 & $\begin{array}{l}\text { Persistent fever erythematous change of } \\
\text { the tongue, dry cracked and bleeding lips. } \\
\text { Diagnosis: Kawasaki disease }\end{array}$ & $\begin{array}{l}\text { WBC: } 8 \times 10^{9} / \mathrm{L} \text {, platelets: } 316 \times 10^{9} / \mathrm{L}, \mathrm{Hb}: \\
\quad 8.6 \mathrm{~g} / \mathrm{dL} \\
\text { CRP: } 182 \mathrm{mg} / \mathrm{L} \\
\text { Echocardiogram: normal }\end{array}$ & $\begin{array}{l}\text { IV immunoglobulin at } 2 \mathrm{~g} / \mathrm{kg} \text { and low-dose } \\
\text { aspirin at } 3 \mathrm{mg} / \mathrm{kg} / \text { day }\end{array}$ \\
\hline Day 7 & Fever resolved & & Discharged on low-dose aspirin \\
\hline May 2019 & Follow-up visit: no signs and symptoms & Normal echocardiogram and CRP & Aspirin stopped \\
\hline
\end{tabular}

CRP: c-reactive protein, WBC: white blood cells, $\mathrm{Hb}$ : hemoglobin, IV: intravenous, DNS: dextrose normal saline 


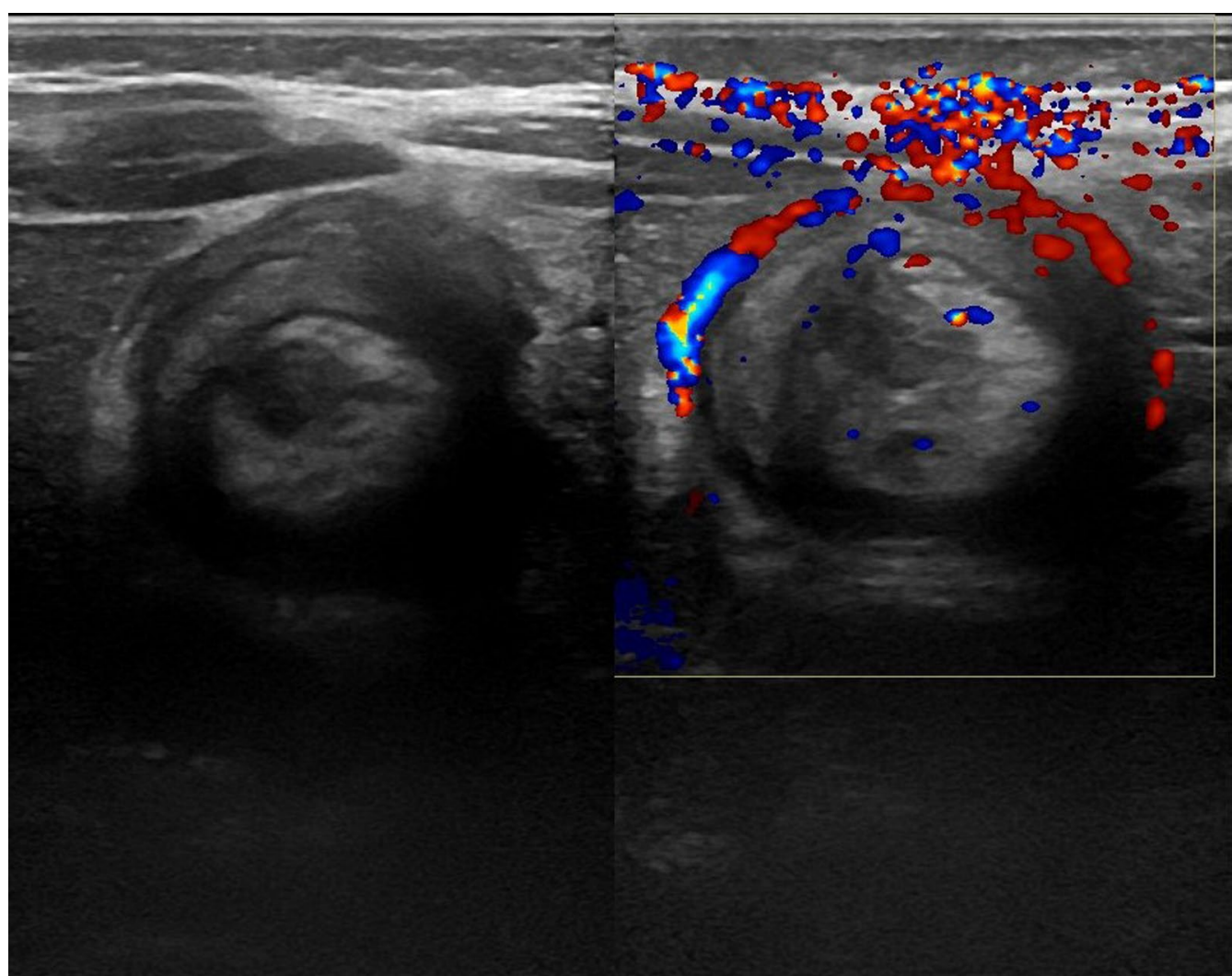

Fig. 1 Ultrasound showing target sign with peripheral vascularity

associated with several episodes of watery yellowish, nonbloody, nonmucoid stools, and skin rash on the back that started at the site of bacillus Calmette-Guerin (BCG) scar on the right arm. On examination, he was irritable and febrile with temperature of $39.9{ }^{\circ} \mathrm{C}$, and had no lymphadenopathy, no pallor but some dehydration, tachycardia (163 beats per minute), and respiratory rate of 46 breaths per minute. He had peripheral cyanosis with capillary refill of about 4 seconds. There was a hyperemic maculopapular rash on the back and at the BCG vaccination site. His abdomen was soft, nontender, and not distended. He had hyperactive bowel sounds with a clean surgical wound.

Workup was done that showed CRP $121 \mathrm{mg} / \mathrm{L}$, WBC $16.83 \times 10^{9} / \mathrm{L}$, neutrophils $54 \%$, lymphocytes $33.9 \%$, platelets $428 \times 10^{9} / \mathrm{L}$, hemoglobin $9.1 \mathrm{~g} / \mathrm{dL}$, normal stool routine [no red blood cells (RBC), leukocytes, cysts, or ova], and normal urine routine (no pus cells or RBC, negative nitrites), and blood culture was done in the following manner: $1 \mathrm{ml}$ of blood was collected aseptically in a BD BACTEC bottle and cultured for 7 days using an automated blood culture system and using fluorescent technology to detect growth; however, no growth was detected. An abdominal X-ray was obtained, which showed no free gas in the abdomen, and abdominal ultrasound showed no fluid collection with normal bowel peristalsis. A diagnosis of presumed intraabdominal sepsis was made, and intravenous amikacin at $15 \mathrm{mg} / \mathrm{kg} /$ day was added to metronidazole and ceftriaxone. Normal saline bolus $160 \mathrm{ml}$ was administered, after which perfusion improved. He was then maintained on intravenous dextrose saline, zinc sulfate $20 \mathrm{mg}$ once a day for diarrhea, and oral ibuprofen $10 \mathrm{mg} / \mathrm{kg} /$ dose and oral paracetamol $15 \mathrm{mg} / \mathrm{kg} /$ dose for fever control. On the fifth day post-surgery, fever and irritability persisted, and the child now developed swelling of both feet and bilateral nonpurulent conjunctivitis sparing the limbus. Serology for dengue was done, which was negative. On day 6 post-laparotomy, erythematous change of the tongue was noticed with dry cracked and bleeding lips. The fever was persistent, and a repeat workup was done: CRP $182 \mathrm{mg} / \mathrm{L}$, WBC $8 \times 10^{9} / \mathrm{L}$, platelets $316 \times 10^{9} / \mathrm{L}$, and hemoglobin $8.6 \mathrm{~g} / \mathrm{dL}$. A diagnosis of Kawasaki disease was made, which met four out of the five criteria (rash, eye changes, mucous membrane changes, extremity changes), and intravenous immunoglobulin at $2 \mathrm{~g} / \mathrm{kg}$ was given with low-dose oral aspirin at $3 \mathrm{mg} / \mathrm{kg} /$ day. An echocardiogram was done, which found normal coronary arteries. Within 
24 hours of the intravenous immunoglobulin (IVIG), the child was fever free and was discharged the following day on low-dose aspirin. On follow-up 48 hours later, CRP was $34 \mathrm{mg} / \mathrm{L}$ and swelling of hands and feet had resolved. He was scheduled for cardiology follow-up, which was normal.

\section{Discussion}

Gastrointestinal presentation such as abdominal pain, vomiting and diarrhea occurs in $25-30 \%$ of Kawasaki cases [4]. This can cause diagnostic delay, especially when diagnostic criteria are lacking during the febrile phase. In an Italian study, $4.6 \%$ of patients with Kawasaki disease presented with acute surgical abdomen [5], which included hydrops of the gall bladder, ischemic colitis, mesenteric and splenic ischemia, hemorrhagic duodenitis, appendicular involvement, and intussusception.

There are four reported cases of Kawasaki disease associated with intussusceptions in literature, of which two presented with intussusception after diagnosis of Kawasaki disease: a 3-year-old girl with ileocolic intussusception [6] and a 4-month-old girl with ileocecal intussusception [7]. The other two presented with intussusception prior to diagnosis of Kawasaki disease: a 3 -year-old boy with colocolic intussusception that was later recognized as Kawasaki disease [8] and a 3-monthold boy [8].

In our case, the child first presented to the hospital with acute onset of vomiting and bloody mucoid stool without fever or other Kawasaki diagnostic criteria features; hence, he was diagnosed with intussusception. On subsequent admission, he presented with peripheral cyanosis and capillary refill time of 4 seconds, which needed fluid boluses for correction, very high CRP $(121 \mathrm{mg} / \mathrm{L})$, and platelets at the higher end of normal range $\left(428 \times 10^{9} / \mathrm{L}\right)$ with a history of laparotomy a week prior, leading us to our initial diagnosis of sepsis. However, negative imaging tests, nonresponse of fever, overall clinical condition, increasing $\mathrm{C}$-reactive protein in spite of being on three different antibiotics, and development of the mucocutaneous features of Kawasaki disease confirms that this was not sepsis.

A relationship between gastrointestinal (GI) symptoms and Kawasaki disease has been hypothesized by Yamashiro, who reported GI tract as one of the primary entry portal for bacterial toxins that affect the immune system by acting as superantigens in Kawasaki disease [9].

The pathogenesis of intussusception depends on the underlying causes, which include lead point (Meckel's diverticulum, polyp, duplication cyst, tumor, hematoma, or vascular malformation). Infections, both viral and bacterial, can stimulate lymphatic tissue in the intestinal tract, resulting in hypertrophy of Peyer's patches in the lymphoid-rich terminal ileum, which may act as a lead point for ileocolic intussusception. Similarly, Kawasaki disease is associated with inflammatory changes of the bowel wall and vasculitis, which could act as a lead point for intussusception.

Kawasaki disease has been reported fewer times in Africa compared with Asia, America, and Europe [2]. This is the third case of Kawasaki disease to be reported in Tanzania and probably the first to present with intussusception. There is likelihood that the two conditions are associated; KD could have resulted in vasculitis and aneurysm of medium-sized submucosal vessel of the ileum or a hypertrophied Peyer's patch that could have acted as a lead point for intussusception.

\section{Conclusion}

It is very important to consider Kawasaki disease in children who are diagnosed with intussusception presenting with or followed by a febrile illness. Our case serves as a reminder that Kawasaki disease may present variably, and not every fever associated with a surgical abdomen is sepsis.

\section{Abbreviations}

KD: Kawasaki disease; IVIG: Intravenous immunoglobulin; CRP: C-reactive protein; WBC: White blood cells; IV: Intravenous; BCG: Bacillus Calmette-Guerin; RBC: Red blood cell; DNS: Dextrose normal saline; GI: Gastrointestinal.

\section{Acknowledgements \\ Not applicable.}

\section{Authors' contributions}

All authors contributed equally to the write up of this article. All authors read and approved the final manuscript.

Funding

Not applicable.

Availability of data and materials

Not applicable.

\section{Declarations}

Ethics approval and consent to participate Not applicable.

\section{Consent for publication}

Written informed consent was obtained from the patient's legal guardian or next of kin for publication of this case report and any accompanying images. A copy of the written consent is available for review by the Editor-in-Chief of this journal.

\section{Competing interests}

The authors declare that they have no competing interests.

\section{Author details}

${ }^{1}$ Aga Khan Hospital, Dar es Salaam, Tanzania. ${ }^{2}$ Muhimbili University of Health and Allied Science, Dar es Salaam, Tanzania. 
Received: 8 October 2019 Accepted: 4 June 2021

Published online: 23 June 2021

\section{References}

1. Kawasaki disease: practice essentials, background, pathophysiology. https://emedicine.medscape.com/article/965367-overview. Accessed 17 Sep 2019.

2. Noorani M, Lakhani N. Kawasaki disease: two case reports from the Aga Khan Hospital, Dar es Salaam-Tanzania 11 medical and health sciences 1102 cardiorespiratory medicine and haematology 11 medical and health sciences 1117 public health and health services. BMC Pediatr. 2018. https://doi.org/10.1186/s12887-018-1306-5.

3. Kawasaki disease: clinical features and diagnosis-UpToDate. https:// www.uptodate.com/contents/kawasaki-disease-clinical-features-anddiagnosis. Accessed 19 Sep 2019.

4. Fabi M, Corinaldesi E, Pierantoni L, Mazzoni E, Landini C, Bigucci B, et al. Gastrointestinal presentation of Kawasaki disease: a red flag for severe disease? PLoS ONE. 2018. https://doi.org/10.1371/journal.pone.0202658.
5. Zulian F, Falcini F, Zancan L, Martini G, Secchieri S, Luzzatto C, et al. Acute surgical abdomen as presenting manifestation of Kawasaki disease. J Pediatr. 2003;142(6):731-5.

6. Caty MG, Stylianos S, Lillehei CW. Ileocolic intussusception in Kawasaki's disease. Pediatr Surg Int. 1994;9(8):590-1.

7. Huang YC, Lin TY, Su WJ. Unusual manifestations in children with Kawasaki disease. J Formos Med Assoc. 1997;96(6):451-6.

8. Hussain RN, Ruiz G. Kawasaki disease presenting with intussusception: a case report. Ital J Pediatr. 2010;36(1):7. https://doi.org/10.1186/ 1824-7288-36-7.

9. Yamashiro Y, Nagata S, Ohtsuka Y, Oguchi S, Shimizu T. Microbiologic studies on the small intestine in Kawasaki disease. Pediatr Res. 1996;39(4):622-4. https://doi.org/10.1203/00006450-199604000-00010.

\section{Publisher's Note}

Springer Nature remains neutral with regard to jurisdictional claims in published maps and institutional affiliations.
Ready to submit your research? Choose BMC and benefit from:

- fast, convenient online submission

- thorough peer review by experienced researchers in your field

- rapid publication on acceptance

- support for research data, including large and complex data types

- gold Open Access which fosters wider collaboration and increased citations

- maximum visibility for your research: over 100M website views per year

At BMC, research is always in progress.

Learn more biomedcentral.com/submissions 